\title{
Anti-Tumor Necrosis Factor Modulates Anti-CD3- triggered T Cell Cytokine Gene Expression In Vivo
}

\author{
Christiane Ferran, * François Dautry," Sylvie Mérite, * Katleen Sheehan," Robert Schreiber,' Georges Grau," \\ Jean-François Bach, * and Lucienne Chatenoud* \\ *Institut National de la Sante et de la Recherche Medicale, U-25, Hôpital Necker, 75743 Paris, France; ${ }^{\ddagger}$ Laboratoire d’Oncologie \\ Moléculaire Centre National de la Recherche Scientifique UA 1158, Institut Gustave Roussy, 94805 Villejuif, France; ${ }^{8}$ Washington \\ University, St. Louis, Missouri; and "World Health Organization Immunology Research and Training Center, \\ Department of Pathology, University of Geneva, Geneva, Switzerland
}

\begin{abstract}
De novo expression of TNF, IFN $\gamma$, IL-3, IL-4, and IL-6 genes was initiated rapidly by treatment of mice with anti-CD3. A specific feature of this reaction was that TNF was derived exclusively from $T$ cells. TNF was produced both as a mature soluble trimeric protein and as a $26-\mathbf{k D}$ anti-TNF-reactive protein compatible with membrane-anchored TNF. Pretreatment with antiTNF did not affect anti-CD3-triggered TNF mRNA expression in $T$ cells. In contrast, in vivo and in vitro anti-TNF treatment upregulated anti-CD3-induced IFN $\gamma$ mRNA expression and inhibited IL $-4 \mathrm{mRNA}$ expression. These latter effects were not dependent on TNF neutralization: pretreatment with soluble recombinant 55-kD TNF receptor (TBPI) as an alternative TNF-neutralizing agent did not modify the anti-CD3-induced cytokine profile. These results suggest that a direct interaction between anti-TNF and T cell membrane-anchored TNF could account for the observed modulation of cytokine gene expression. The increased expression of INF $\gamma$ mRNA observed in anti-TNF-treated animals correlated with a decrease in IL-3 and IL-6 mRNA expression. Conversely, IFN $\gamma$ blockade by a neutralizing anti-IFN $\gamma$ mAb led to a substantial increase in both IL-3 and IL-6 gene expression induced by anti-CD3. Taken together, these results strongly argue for the existence, in the anti-CD3-induced cytokine cascade, of IFN $\gamma$-dependent regulation of IL-3 production, which in turn modulates IL-6 production. (J. Clin. Invest. 1994. 93:2189-2196.) Key words: $T$ cell activation • tumor necrosis factor $\cdot \mathrm{CD} 3 \cdot$ immunosuppression $\cdot$ cytokines
\end{abstract}

\section{Introduction}

Many experimental models associated with release of substantial amounts of cytokines into the circulation involve the almost exclusive activation of monocyte/macrophages; this is the case of endotoxin-mediated septic shock, tuberculosis, and sarcoidosis (1-3). Anti-CD3 mAb treatment is unique in its ability to induce massive polyclonal $\mathrm{T}$ cell activation in vivo

Address correspondence to Dr. L. Chatenoud, INSERM U 25, Hôpital Necker, 75743 Paris, Cedex 15, France.

Received for publication 5 May 1993 and in revised form 29 November 1993

J. Clin. Invest.

(C) The American Society for Clinical Investigation, Inc.

0021-9738/94/05/2189/08 $\$ 2.00$

Volume 93, May 1994, 2189-2196
(4-7). Over 100 genes are activated during the process of antigenic stimulation (8). Oncogenes such as c-fos and myc are rapidly expressed, followed by the genes encoding various secretory products. The latter include cytokines (IL-2, IL-4, IFN $\gamma$, IL-6, TNF, and others) that are crucial in initiating the differentiation of $\mathrm{T}$ and $\mathrm{B}$ lymphocytes, as well as monocytes/ macrophages (9). After a first injection ( $10 \mu \mathrm{g}$ i.v.) of the hamster anti-murine CD3 mAb 145 2C11, BALB/c mice transiently release into the circulation several cytokines, including TNF, IL-2, IL-3, IL-4, and IL-6 and IFN $\gamma$ (5-7). This leads to a severe but self-limiting physical syndrome associating diarrhea, hypothermia, and hypomotility (5-7). Both the physical syndrome and the cytokine release mimic the clinical OKT3 (anti-human CD3)-induced reaction (10). We used two anticytokine mAbs, hamster anti-murine TNF and IFN $\gamma$, to dissect out the respective roles of each of these cytokines in the induction of the anti-CD3-triggered cascade. Anti-TNF mAb prevented most of the physical signs, whereas anti-IFN $\gamma$ mAb was ineffective; furthermore, the latter abrogated the beneficial effect of anti-TNF after combined pretreatment (11). Kinetic analysis of circulating cytokine levels gave further insight into the mode of action of anti-TNF and anti-IFN $\gamma$. Anti-TNF alone not only neutralized the bioactivity of anti-CD3-induced TNF but also substantially modified the release of the other cytokines, with an increase in anti-CD3-induced IFN $\gamma$ levels (particularly marked at the 4-h peak of secretion), together with a decrease in IL-3 and IL-6 release and a total inhibition of IL-4 release (reference 11 ; personal data). IL-2 production remained unchanged. Anti-IFN $\gamma$ treatment did not modify TNF, IL-2, or IL-4 levels but, conversely to anti-TNF, increased IL-3 and IL-6 release (peaking 4-8 h after anti-CD3 injection). Interestingly, combined treatment with the two mAbs completely neutralized both TNF and IFN $\gamma$ but did not affect IL-3, IL-4, or IL-6 release (11).

Given the beneficial effect of anti-TNF in preventing the anti-CD3-induced syndrome in both animals and humans $(11,12)$, we investigated the molecular basis of its action. Variations in IFN $\gamma$, IL-3, IL-4, and IL-6 levels could be due to a change either in the consumption of the proteins or in their production. As transcriptional control (initiation of RNA synthesis) and posttranscriptional modifications of mRNA stability are the most frequent mechanisms of gene regulation (13), including cytokine gene $(14,15)$, we used RNase protection techniques to measure the degree of cytokine gene expression in various anti-cytokine/anti-CD3-treated groups of mice. The need of reliable quantification of RNA motivated the choice of the RNase protection (or mapping) technique (16, 17). We then investigated the way in which anti-TNF affects the ability of anti-CD3 to trigger cytokine gene expression. 


\section{Methods}

Mice, $m A b s$, and recombinant proteins. BALB/c mice (6-8 wk old) were from IFFA CREDO (L'Arbresle France). 145 2C11 is a hamster IgG mAb specific for the murine CD3 $\epsilon$ chain (18). TN3 19.12 and $\mathrm{H}-22$ are hamster IgG mAbs that respectively block the biological activity of TNF/murine lymphotoxin and IFN $\gamma$ in vivo and in vitro (19, 20 ). $\mathrm{L} 2 \mathrm{mAb}$ (used as control) is an irrelevant hamster IgG mAb directed at recombinant murine IL-2 but that does not recognize natural murine IL-2 (20). TNF-binding protein I (TBPI) ${ }^{1}$ corresponds to the soluble form of the human 55-kD TNF receptor and was produced as a recombinant protein in $\mathrm{CHO}$ cells (kind gift of Dr. A. Ythier Ares-Serono, Geneva, Switzerland); it has been shown to bind both human and murine TNF and to act as a powerful antagonist of TNF activity $(21,22)$.

In vivo treatments. Groups of mice were treated as follows: $250 \mu \mathrm{g}$ i.p. per mouse of TN3 19.12, 12-18 h before the injection of $1452 \mathrm{Cl} 1$ i.v.; $250 \mu \mathrm{g}$ of $\mathrm{H}-22 \mathrm{mAb}$ i.p. before $1452 \mathrm{C11} ; 250 \mu \mathrm{g}$ of the control hamster $\mathrm{mAb}(\mathrm{L} 2)$ before $1452 \mathrm{C} 11 ; 100 \mu \mathrm{g}$ of TBPI 10-30 min before $1452 \mathrm{Cl1}$; and $250 \mu \mathrm{g}$ of the control hamster mAb (L2) before the injection of another irrelevant $\mathrm{mAb}$.

In vitro anti-TNF treatment of anti-CD3-activated splenocytes. 6wk-old BALB/c mice received a 10- $\mu \mathrm{g}$ i.v. injection of $1452 \mathrm{C} 11$. Total spleen cells were recovered at 10,30 , and $60 \mathrm{~min}$ after the anti-CD3 injection. The cells were immediately resuspended at $10 \times 10^{6} \mathrm{cells} / \mathrm{ml}$ in RPMI 1640 supplemented with 10\% FCS and incubated for $1 \mathrm{~h}$ at $37^{\circ} \mathrm{C}$, in a $5 \% \mathrm{CO} 2$ humidified atmosphere, with either the hamster anti-TNF TN3 $19.12 \mathrm{mAb}(25 \mu \mathrm{g} / \mathrm{ml})$ or the control L2 hamster mAb $(25 \mu \mathrm{g} / \mathrm{ml})$. The incubation was performed in $5-\mathrm{ml}$ culture tubes disposed on a roller. At the end of the incubation, after extensive washing in PBS, the cells were used for RNA extraction. RNA protection assays using probes specific for IFN $\gamma$, IL-4, and $\beta$-actin were performed.

Evaluation of body temperature and diarrhea. The mice were tagged and body temperature was recorded by means of an electronic microthermometer (Thermalet; Bailey Instruments Co. Inc., Saddle Brook, $\mathrm{NJ}$ ) in a room at $22-24^{\circ} \mathrm{C}$; diarrhea was noted as present or absent. Body temperature and diarrhea were recorded before anti-cytokine and TBPI injection then before and 4, 24, and $48 \mathrm{~h}$ after anti-CD3 administration. 30 mice were used in each experiment (six for each treatment). The results were comparable from one experiment to another and are given as the means of four experiments.

$R N A$ extraction. RNA was extracted from total spleen cells or from purified splenocyte subsets ( $\mathrm{T}+$ cells, $\mathrm{B}+$ cells, and monocytes ) according to the method described by Chomczynski and Sacchi (23), which involves a single step of acid guanidium thiocyanate/phenol-chloroform extraction. The amount of extracted RNA was calculated from optical density at $260 \mathrm{~nm}$. Purity and integrity were checked in $1 \%$ agarose gels containing ethidium bromide.

$R$ Nase protection assay. $\mathrm{RNase}$ protection assays with specific murine RNA probes were performed on extracted RNA to determine the precise amount of mRNAs encoding the different anti-CD3-induced cytokines $(16,17) .{ }^{32} \mathrm{P}$-Labeled RNA with a specific activity of $6 \times 10^{7}$ $\mathrm{cpm} / \mu \mathrm{g}$ was obtained by in vitro run-off transcription with SP6, T3, or T7 RNA polymerase, depending on the plasmid (24). Hybridization of labeled antisense RNA probes with $10 \mu \mathrm{g}$ of sample RNA was followed by digestion with RNase A and T1 (Sigma, St. Louis, MO). This eliminates residual RNA, thus leaving only the hybrids. The samples were then run in 5\% polyacrylamide-urea gels, dried, and subjected to autoradiography on XAR Kodak film at $-80^{\circ} \mathrm{C}$.

The probes were the murine TNF probe (kind gift from Dr. W. Roeder, Lilly Research Laboratories, Indianapolis IN) containing part of the third intron and fourth exon of murine genomic TNF DNA from a SmaI to SacI sequence, cloned in the PGEM-2 vector. Successful hybridization results in the detection of a 276-bp protected fragment

1. Abbreviations used in this paper: TBPI, TNF-binding protein I; TBS, Tris-buffered saline.
(25). The murine IFN $\gamma$ probe (also a kind gift from Dr. W. Roeder) is a 610-bp cDNA from a HindIII to Xbal sequence inserted in the Bluescript vector. After linearization and further digestion with SspI, T3 polymerase generates a 293-bp antisense RNA transcript. Successful hybridization results in the detection of a 260 -bp protected fragment (26). The murine IL-3 probe is a cDNA fragment subcloned in an EcoRI/HindIII fragment of the Bluescript plasmid (kind gift from Dr. M. Dy, CNRS URA 1461, Paris). After linearization with HindIII and subsequent antisense RNA transcription in vitro using the $T 3$ polymerase, successful hybridization leads to a 309-bp protected fragment (27). The murine IL-4 probe is a cDNA fragment subcloned in the HindII polycloning site of the PGEM-3 vector (kind gift from Dr. W. Paul, National Institutes of Health, Bethesda, MD). Successful hybridization leads to a 373-bp protected band (28). The murine IL-6 probe is a 650-bp cDNA from a HindIII to EcoRI sequence inserted in the PGEM-4 cloning vector (kind gift from Dr. M. Dy, CNRS URA 1461, Paris). After linearization and further digestion with FokI, T7 polymerase generates a 283-bp antisense RNA fragment. Successful hybridization results in the detection of a 263-bp protected fragment (29). A 600 -bp $\beta$-actin murine cDNA probe (pBACT 5 , prepared by Dr. F. Dautry) was concomitantly used to assess the quality and quantity of loaded RNA. pBACT5 is cloned in the TaqI-PSTI site of the Bluescript vector. After linearization and further digestion with Hinf I, T3 polymerase generates a 220-bp antisense RNA fragment. Successful hybridization leads to a 190 -bp protected fragment. Autoradiography signals were quantified by scanning with the NE1 1 OP7 Chromoscan 3 (Joyce, Loebl and Co. Ltd., Gateshead, UK).

Cell purification. Enriched B and T cells and monocytes were separated from total splenocytes before and 1 and $3 \mathrm{~h}$ after anti-CD3 injection. $B$ cells were positively selected with magnetic beads coated with RA-3-6-B2 mAb (a rat IgG mAb directed at the B220 molecule of mouse $B$ lymphocytes). $T$ cells were purified by panning in petri dishes coated with sheep anti-mouse IgG (to eliminate B cells) followed by positive selection on anti-CD4 ( GK 1.5, a rat IgG $2 \mathrm{~b}$ directed at mouse CD4) and anti-CD8 (Lyt 2, a rat IgG $2 \mathrm{~b}$ mAb directed at mouse CD8)-coated Dynabeads (Biosys, Compiègne, France). The monocyte-enriched population was obtained by negative selection after eliminating cells fixed to anti-B- and anti-CD4/CD8-coated Dynabeads. FACS analysis (Becton Dickinson Co., Mountain View, CA) of cells after the different separation procedures was used to determine the purity of each cell subset.

Membrane preparations. Membrane preparations were recovered from purified $\mathrm{T}$ cells before and 1 and $3 \mathrm{~h}$ after anti-CD3 injection. For subcellular fractionation and membrane preparation, 30-100 $\times 10^{6}$ total splenocytes or purified T cells were washed in HBSS, and then suspended in $0.01 \mathrm{M}$ Tris-buffered saline (TBS), $0.01 \mathrm{M} \mathrm{CaCl}_{2}, 0.25$ M sucrose, 0.2 M PMSF (Serva Biochemicals, Paramus, NJ), pH 7.4, and disrupted using a Dounce homogenizer at $4^{\circ} \mathrm{C}$. Homogenates were then centrifuged at $1,000 \mathrm{~g}$ for $10 \mathrm{~min}$. The nuclear and organelleenriched fractions were removed and resuspended in buffer consisting of $2.3 \%$ SDS, $62.5 \mathrm{mM}$ Tris, $10 \%$ glycerol, and $5 \% \beta$-mercaptoethanol, pH 6.8, for one-dimensional gel electrophoresis. The supernatant was centrifuged at $20,000 \mathrm{~g}$ for $60 \mathrm{~min}$, and the membrane-enriched pellet was resuspended in the same SDS buffer for one-dimensional gel electrophoresis. Protein was measured with a commercial kit (BCA; Amersham, les Ulis, France). Control preparations included $\mathrm{T}$ cell membranes recovered from untreated mice and $T$ cell nuclear fractions recovered from anti-CD3-treated mice. For gel electrophoresis and Western blot analysis, $8 \mu \mathrm{g}$ of nuclear or membrane pellet was solubilized in SDS-PAGE loading buffer, boiled for $5 \mathrm{~min}$, and then subjected to electrophoresis in a $12 \%$ polyacrylamide gel according to the method described by Laemmli (30). After electrophoresis, protein was electrotransferred to nitrocellulose membrane filters (Schleicher \& Schuell, Inc., Dassel, Germany) as described by Burnette (31). The filters were then soaked in $3 \%$ gelatine/ $0.02 \mathrm{M}$ TBS, incubated with 20 $\mu \mathrm{g} / \mathrm{ml} \mathrm{TN} 319.12$ (anti-TNF mAb) or a $1 / 50$ dilution of an ascitic anti-murine $\mathrm{H}-2\left(K_{\mathrm{d}}, D_{\mathrm{d}}\right.$ specificity; 34-1-2S clone provided by the American Type Culture Collection, Rockville, MD) ascites (32). All 
antibodies were diluted in $0.02 \mathrm{M}$ TBS containing $1 \%$ gelatine and $0.05 \%$ Tween 20 . After thorough washing, the filters were incubated with biotinylated sheep anti-mouse and anti-hamster Ig (Amersham) diluted $1: 1,000$ in the same buffer, and then washed and incubated with streptavidin-horseradish peroxidase complex (Amersham) diluted 1:5,000 in the same buffer. Revelation was performed using a highly sensitive nonradioactive detection method based on chemiluminescence (Amersham). Briefly, horseradish peroxidase present on the final layer of the protein filter catalyzes the oxidation of luminol in the presence of hydrogen peroxide. Immediately after oxidation, excited luminol decays to the ground state and emits light measurable on special Hyperfilm-ECL. Molecular weight markers were phosphorylase b (94 kD), BSA (67 kD), ovalbumin (43 kD), carbonic anhydrase (30 kD), soybean trypsin inhibitor (20.1 kD), and $\alpha$-lactalbumin (14.4 kD) (Pharmacia LKB Biotechnology Inc., Uppsala, Sweden).

Statistical analysis. Variations in body temperature with time after the various treatments were analyzed using analysis of variance and repeated measures. Post hoc tests were used to delineate temporal differences between treatment and placebo at each time. Other comparisons of mean values were made using Student's $t$ test.

\section{Results}

Kinetics of anti-CD3-induced cytokine gene expression in vivo. In all experiments, total RNA was extracted from splenocytes before and $0.25,0.5,1,4,8$, and $24 \mathrm{~h}$ after anti-CD3 injection. Expression of specific cytokine mRNA was quantified in RNase protection assays. Except for very low IL-6 mRNA levels, no cytokine gene expression was detected before anti-CD3 administration (Fig. $1 A$ ). TNF transcripts started to be expressed as early as $15 \mathrm{~min}$ after anti-CD3 administration, peaked at $30 \mathrm{~min}$, and remained stable up to $8 \mathrm{~h}$ (Fig. $1 A$ ). IFN $\gamma$ mRNA was detectable at $30 \mathrm{~min}$ and peaked at $4 \mathrm{~h}$; levels were still high at $8 \mathrm{~h}$ but then became undetectable. IL-3 transcripts were detected at 30 min and peaked between 4 and $8 \mathrm{~h}$. Both IL-2 and IL-4 mRNA were detected at 30 min but disappeared within 4-8 h (results not shown for IL-2). IL-6 mRNA expression became detectable at only $1 \mathrm{~h}$ but was much more durable, being present at $24 \mathrm{~h}$ (Fig. $1 A$ ).

Anti-CD3-induced TNF was exclusively $T$ cell derived. $\mathrm{Pu}-$ rified cell populations were isolated from total splenocytes before and 1 and $3 \mathrm{~h}$ after the anti-CD3 challenge. RNA extracted from total splenocytes and from enriched subsets (B cells, $T$ cells, and monocytes) were hybridized with the ${ }^{32} \mathrm{P}$-labeled murine TNF probe in RNase protection assays. No TNF mRNA was detected in the monocyte-enriched preparation $1 \mathrm{~h}$ after anti-CD3 injection (Fig. 2), whereas large amounts were present in T cells (Fig. 2). A weak signal was detected in B cells, but this was due to contamination with anti-CD3-coated $T$ cells. Indeed, the anti-CD3 $1452 \mathrm{C} 11$ cross-reacts with the rat antimouse $\mathrm{B}$ cell $\mathrm{mAb}$ coating the magnetic beads used in $\mathrm{B}$ cell purification. FACS ${ }^{\circledR}$ analysis confirmed that the $\mathrm{T}$ cells and monocytes were $90-95 \%$ pure, whereas B cell purity was 80 $85 \%$; the contaminant cells stained positively with CD4 and CD8 FITC mAbs, confirming that they were $\mathrm{T}$ cells coated with $1452 \mathrm{C} 11$.

In vivo treatment with anti-TNF and anti-IFNy modulate anti-CD3-induced cytokine gene expression. No cytokine gene expression was induced by the administration of the anticytokine antibodies ( anti-TNF, anti-IFN $\gamma$ ) or the control mAb L2. Anti-TNF did not regulate the transcriptional rate of the TNF gene, as TNF mRNA levels were not modified by anti-TNF. However, levels of IFN $\gamma$ mRNA in anti-TNF-treated mice
(A)

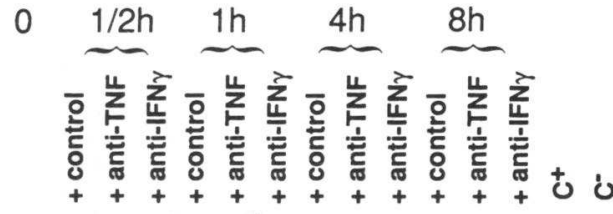

$\mathrm{TNF} \alpha$

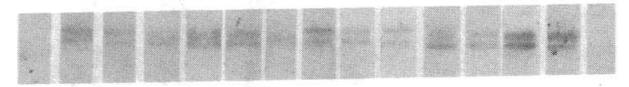

IFN $\gamma$

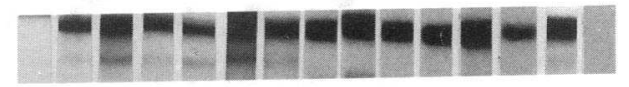

IL-3

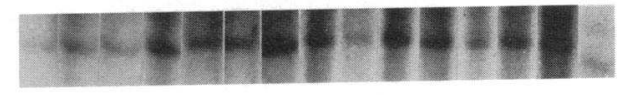

IL-4

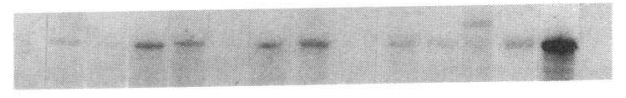

IL-6

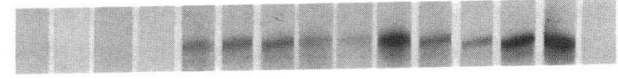

Bactin
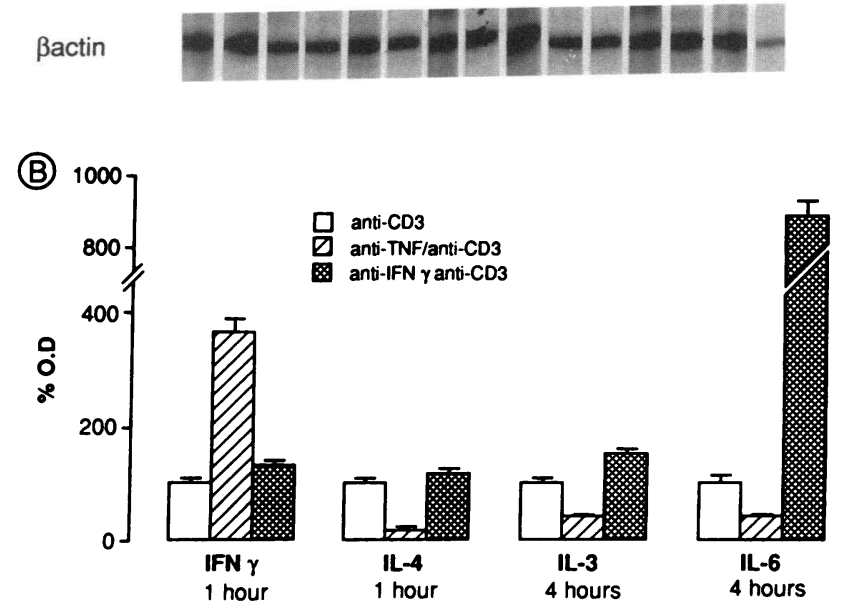

Figure 1. (A) RNase protection assays performed on total spleen cell RNA hybridized to specific antisense murine RNA probes in three groups of mice after an anti-CD3 administration. Note the increase in IFN $\gamma$ mRNA levels in anti-TNF-pretreated mice at all time points. IL-4 mRNA was no longer detectable in anti-TNF/anti-CD3-treated mice. IL-3 and IL-6 mRNA levels were decreased in the anti-TNF group and increased in the anti-IFN $\gamma$ group. TNF mRNA levels were the same in the three groups, as were IL-2 mRNA levels (data not shown). A murine $\beta$-actin probe was used to assess the purity and quantity of loaded RNA, even though $\beta$-actin is slightly (20\%) inducible after anti-CD3 administration. Figures shown are results depicted from one representative experiment of four. $(B)$ mRNA levels $(O D)$ are expressed as percentage increases or decreases relative to controls. Results are the means of four experiments performed with different RNA samples.

were significantly higher (60-250\% on autoradiographs; $P$ $<0.001$ ) (Fig. 1, $A$ and $B$ ) than in control anti-CD3-treated animals at all times between $30 \mathrm{~min}$ and $8 \mathrm{~h}$ ). In contrast, IL-3 and IL-6 mRNA levels fell significantly $(90-150 \% ; P<0.001)$, especially at 4 and $8 \mathrm{~h}$ (Fig. $1 A$ and $B$ ). Finally, anti-TNF mAb pretreatment totally inhibited IL-4 mRNA production. AntiIFN $\gamma$ did not modify the transcriptional rate of IFN $\gamma$, TNF, or IL-4 genes (Fig. $1 \mathrm{~A}$ ), whereas it led to a $75-100 \%$ increase in IL-3 mRNA and an 85-800\% increase in IL-6 mRNA. This 


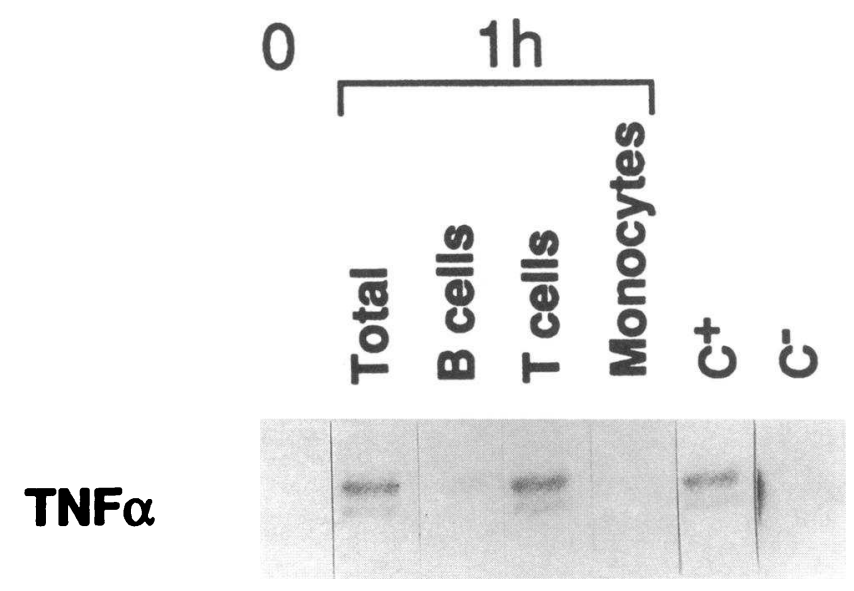

Figure 2. RNase protection assays with a murine TNF probe on RNA extracted from purified $\mathrm{T}$ cell, $\mathrm{B}$ cell, and monocyte populations after anti-CD3 administration. The results show that the anti-CD3-induced TNF was $T$ cell derived. Four experiments were performed, using different RNA samples and showed the same results.

pattern was a mirror image of that obtained after anti-TNF pretreatment. IL-2 mRNA levels were not modified by either anticytokine treatment, in accordance with reported data for circulating levels (11).

In vitro effect of anti-TNF on anti-CD3-induced activation. To further support the direct effect of anti-TNF in modulating $\mathrm{T}$ cell anti-CD3-induced cytokines, in vitro experiments were performed. Spleen cells were recovered at different time points $(10,30$, and $60 \mathrm{~min})$ after a $10 \mu \mathrm{g}$ i.v. anti-CD3 injection. The cells were then incubated in vitro for $1 \mathrm{~h}$ with anti-TNF or the control L2 mAb. As shown in Fig. 3, anti-TNF treatment significantly affected the levels of anti-CD3-induced IFN $\gamma$ - and IL4-specific mRNAs. Quantification of the autoradiography signals in cells recovered at 10 and $30 \mathrm{~min}$ after anti-CD3 injection disclosed a $104 \%$ and $57.7 \%$ signal increase of IFN $\gamma$ mRNA, respectively, compared with controls. At the same time points, a $60.7 \%$ and $42.5 \%$ decrease of IL-4 mRNA compared with controls was observed.

In vivo effect of TBPI on anti-CD3-induced activation. One way to envisage anti-TNF-related regulation of IFN $\gamma$ and IL-4 production is to assume that TNF has a negative immunoregulatory effect on IFN $\gamma$ mRNA expression and a positive effect on IL-4 mRNA expression. Thus, by interfering with the action of TNF when preventing its binding to TNF receptors, one would inhibit this signaling pathway. To test this hypothesis, we used TBPI, the recombinant soluble form of the human $55-\mathrm{kD}$ TNF receptor. TBPI ( $100 \mu \mathrm{g}$, a dose that prevents lethality in an experimental septic shock model; G. Grau et al., personal results) was injected to BALB/c mice before anti-CD3 $(10 \mu \mathrm{g})$. TBPI totally prevented both lethality $(10-15 \%$ of adult mice usually die after this anti-CD3 dose) and anti-CD3induced hypothermia. At $4 \mathrm{~h}$, when body temperature is minimum, all TBPI-pretreated mice had a normal temperature (mean $\pm \mathrm{SD} ; 37 \pm 0.3$ vs. $35.3 \pm 0.2^{\circ} \mathrm{C}$ in anti-CD3-treated mice). In contrast, diarrhea, a later reaction, was less effectively prevented than by anti-TNF treatment $(60 \%$ vs. $0 \%)$ (Fig. 4).

RNase protection assays were performed with the murine TNF, IFN $\gamma$, IL-3, IL-4, and IL-6 probes on RNA extracted

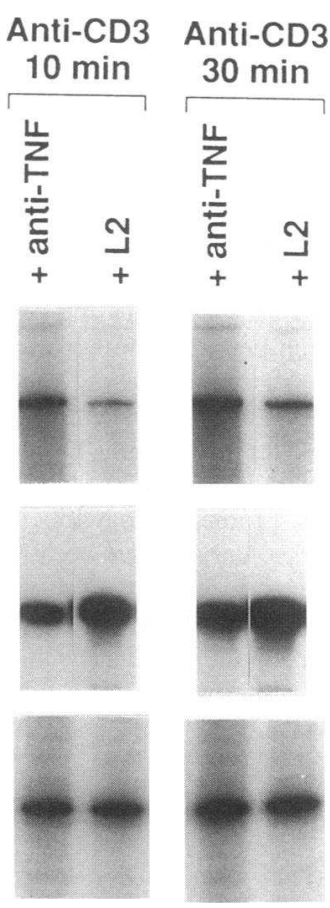

Figure 3. Spleen cells recovered from mice injected with $10 \mu \mathrm{g}$ i.v. of anti-CD3 were recovered at different times ( 10 and $30 \mathrm{~min}$ ) and incubated in vitro for $1 \mathrm{~h}$ with anti-TNF or the control L2 mAb. RNAse protection assays performed on RNA samples extracted at the end of the in vitro incubation from anti-TNF-treated and L2 (control $\mathrm{mAb}$ )-treated cells are shown (results are from one representative experiment of three that were performed). Anti-TNF significantly upmodulated the levels of anti-CD3-induced IFN $\gamma$ RNA (at 10 min: $104 \%$ signal increase compared with control; at $30 \mathrm{~min}$ : $57.7 \%$ signal increase compared with control) and downmodulated IL-4 mRNA (at 10 min: $60.7 \%$ signal decrease compared with control; at 30 min: $42.5 \%$ signal decrease compared with control).

from total splenocytes of TBPI/anti-CD3-treated animals at the time points previously studied and the autoradiography signals were compared with those obtained with anti-CD3 and anti-TNF/anti-CD3-treated animals. Conversely to the effects

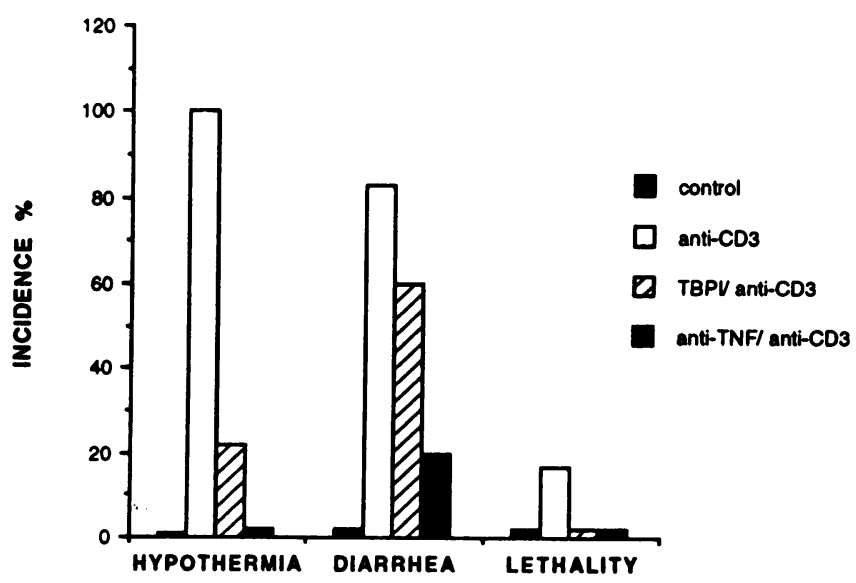

Figure 4. TBPI significantly affected the anti-CD3-induced physical syndrome. The incidence of hypothermia, diarrhea, and lethality is detailed for TBPI and anti-TNF-pretreated mice, for mice only receiving anti-CD3, and for untreated controls (Control groups are indicated by the first black bar per syndrome.). 

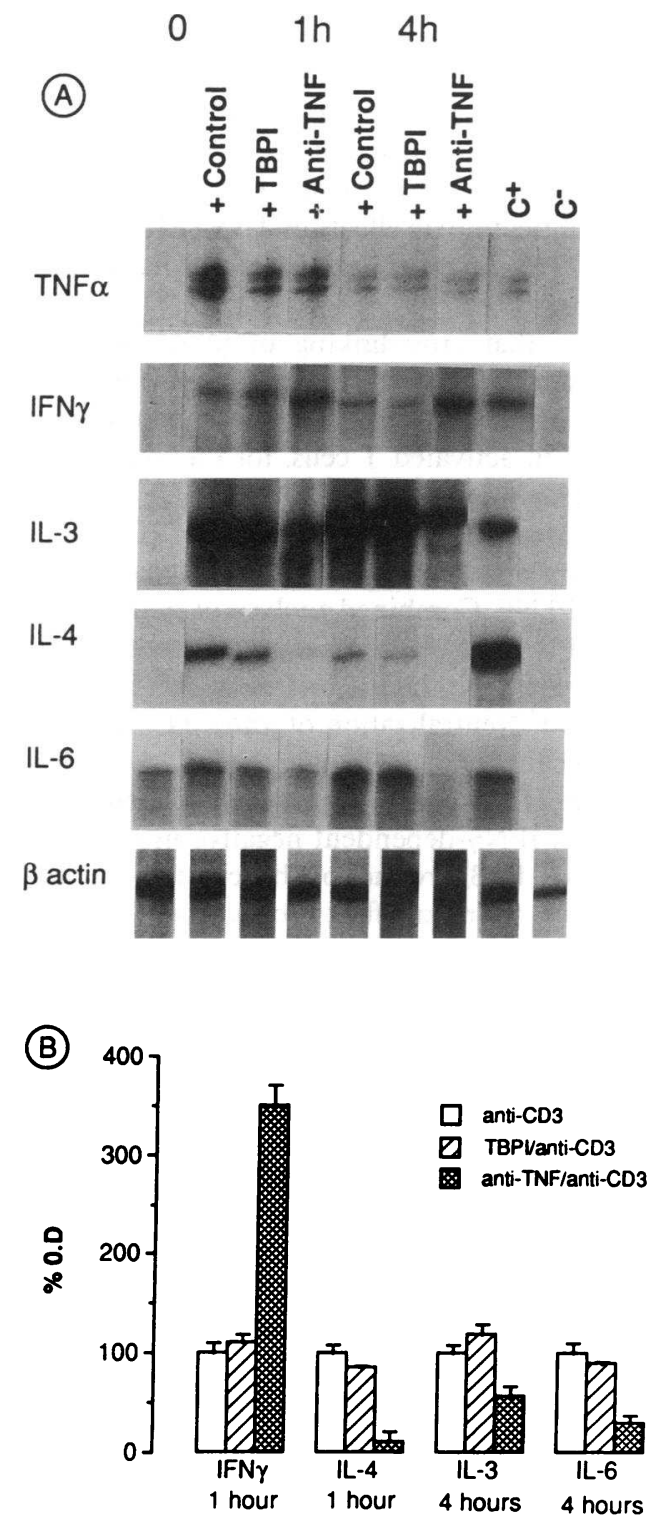

Figure 5. (A) RNase protection assays with total spleen cell RNA hybridized to specific murine RNA probes in anti-CD3-, TBPI/antiCD3-, and anti-TNF/anti-CD3-treated mice. There were no significant modifications of cytokine mRNA levels in the TBPI/anti-CD3 group relative to the anti-CD3 group. Figures shown are taken from one representative experiment of four. $(B)$ mRNA levels $(O D)$ are expressed as percentage increases or decreases relative to controls.

of anti-TNF, TBPI pretreatment did not affect any of the cytokine mRNAs analyzed. As shown in Fig. 5, $A$ and $B$, the pattern of RNA transcripts was totally superimposable in mice receiving only anti-CD3 and those pretreated with TBPI.

Anti-CD3-activated $T$ cells express membrane-anchored $T N F$. As the above results suggested that blockade of TNF bioactivity was not in itself sufficient to modulate IFN $\gamma$, IL-3, IL-4, and IL-6 mRNA expression, we postulated a direct interaction between anti-TNF and T lymphocytes. As proposed in other models, membrane-anchored TNF would be a candidate target for such an interaction. This molecule has been recently detected on both monocytes and in vitro-activated $T$ cells, which were the sole source of TNF in our model (33-35).
To test this hypothesis, we looked for the presence of a specific anti-TNF target on $\mathrm{T}$ cells activated by anti-CD3 in vivo. Western blot analysis of membrane preparations recovered from the purified $T$ cell population revealed the expression of a membrane-associated form of TNF that was detectable within $1 \mathrm{~h}$ and showed maximal expression at $3 \mathrm{~h}$ (Fig. 6). Using the same anti-TNF mAb injected in vivo, we revealed a 26-kD molecule, fitting well with the reported molecular weight of the typical type II membrane-anchored TNF protein (33). Immunodetection using an anti-murine $\mathrm{H} 2 \mathrm{mAb}\left(K_{\mathrm{d}} D_{\mathrm{d}}\right.$ specificity) revealed the specific expression on $\mathrm{T}$ cell membrane preparations of class I MHC molecules, the expression of which was also increased 1 and $3 \mathrm{~h}$ after anti-CD3 administration.

\section{Discussion}

Anti-CD3 mAbs are an excellent tool for investigating the molecular mechanisms of the cytokine cascade elicited in vivo by polyclonal triggering of the $\mathrm{CD} 3 / \mathrm{T}$ cell receptor complex. The gene encoding TNF was the first to be induced after anti-CD3 administration. Its mRNA was present in large amounts at 15 min, peaked at $30 \mathrm{~min}$, and remained relatively stable up to 8 h. The induction of IFN $\gamma$ and IL-4 genes was detected at 30 min, reached a maximum between 1 and $4 \mathrm{~h}$, and started declining after $8 \mathrm{~h}$. IL-3 mRNA showed a similar kinetic pattern, although peak levels were detected later (4-8 h). IL-6 gene induction showed delayed kinetics, with mRNA appearing by $1 \mathrm{~h}$ but being detectable up to $24 \mathrm{~h}$. These results confirm and extend the data reported by Scott et al. (36), although we observed more durable anti-CD3-induced IL-4 mRNA expression. This difference is probably due to the higher anti-CD3 dose used in this study ( $10 \mathrm{vs.} 4 \mu \mathrm{g}$ ).

Selective blockade of given cytokines with neutralizing mAbs can be used to identify new cytokine regulatory pathways. As we have already reported, pretreatment of anti-CD3treated mice with an anti-TNF mAb totally neutralizes the circulating TNF activity induced by anti-CD3, at the same time significantly altering the overall pattern of the cytokine cascade. Anti-TNF pretreatment also almost completely inhibits the acute physical syndrome (11). At the molecular level, the patterns of cytokine gene expression in anti-cytokine/antiCD3-treated mice showed some peculiar features. Importantly, anti-TNF mAb did not affect TNF transcription, contrary to observations by Kindler et al. (37) in experimental granulomatous tuberculosis. Various elements may account

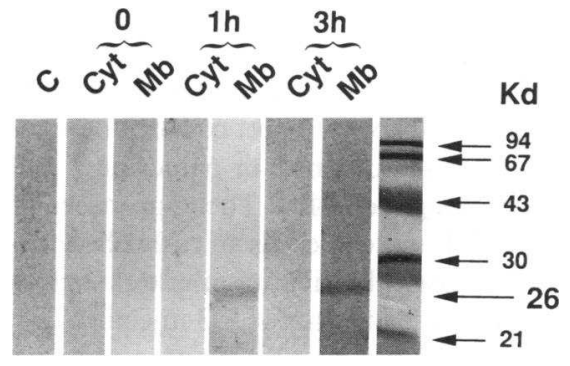

Figure 6. Western blot analysis of $\mathrm{T}$ lymphocyte membrane preparations using the anti-TNF mAb revealed $26-\mathrm{kD}$ membrane-bound TNF at 1 and $3 \mathrm{~h}$ after the anti-CD3 challenge. The figure shows one experiment of three. 
for this discrepancy, including the cell source of TNF (macrophages in the granulomatous tuberculosis model and $\mathrm{T}$ cells in the anti-CD3 model) and the kinetics of TNF production (chronic in the former and acute in the latter). Indeed, analysis of RNA extracted from purified spleen cell subsets ( $T$ cells, B cells, and monocytes) revealed the exclusive $T$ cell origin of anti-CD3-induced TNF, further confirming the ability of $T$ cells to produce TNF (38-40). No TNF-encoding transcripts were detected in monocytes at any of the time points analyzed, even though anti-CD3-induced activation is monocyte dependent (41). $\mathrm{F}\left(\mathrm{ab}^{\prime}\right)_{2}$ fragments are not mitogenic in vitro and, in vivo, do not promote the massive cytokine release or acute physical syndrome regularly observed with the entire antibody (41). In contrast to TNF, monocyte IL- $1 \beta$ and IL-6 genes are induced within hours of anti-CD3 administration (C. Ferran et al., manuscript submitted for publication).

In vivo anti-TNF significantly modulated the expression of various other cytokine genes in the anti-CD3-induced cascade. It significantly upregulated levels of IFN $\gamma$ mRNA, whereas it decreased those of IL-3 and IL-6 mRNA and totally abrogated IL-4 gene transcription. These changes in mRNA levels could be due to pretranscriptional regulation, as is often the case of cytokine gene expression (14) or, alternatively, to modifications of mRNA stability (42). Interestingly, the capacity of anti-TNF to upregulate IFN $\gamma$ mRNA and to downregulate IL$4 \mathrm{mRNA}$ could also be evidenced in an in vitro model. In these experiments splenocytes were collected at 10 and $30 \mathrm{~min}$ after anti-CD3 injection and incubated in vitro with anti-TNF or a control $\mathrm{mAb}$. In this in vitro system, anti-TNF $\mathrm{F}\left(\mathrm{ab}^{\prime}\right)_{2}$ fragments showed the same modulating properties on anti-CD3induced IFN $\gamma$ and IL-4 mRNAs as the whole antibody (data not shown).

The effect of anti-TNF on IFN $\gamma$ mRNA levels raises two hypotheses. In the first, mAb-mediated inhibition of TNF binding to its specific receptor would prevent it from exerting a regulatory effect. The second involves signal triggering through a direct interaction between anti-TNF and T lymphocytes. In support of this second possibility, our data suggest that, after anti-CD3 activation, $T$ cells express a membrane-associated TNF molecule within $1 \mathrm{~h}$ of stimulation. This would be an ideal target for administered anti-TNF (33-35). Indeed, Western blot analysis showed the presence on purified activated $\mathrm{T}$ cell membranes of a 26-kD anti-TNF-reactive protein compatible with the described membrane-anchored TNF (33). Furthermore, as described by Kriegler et al. (33) this molecule does not correspond to the molecular weight signal one would expect if the anti-TNF-reactive material was soluble TNF (17-kD monomer or $50-\mathrm{kD}$ multimer) bound to its receptor $(40,43$, 44). Several reports in the literature point to the functional relevance of this membrane-associated TNF. In particular, membrane-associated TNF seems to be as potent as the soluble trimer in inducing tumor lysis through direct cell-cell contact $(33,43)$. Moreover, a role as an autocrine or paracrine $\mathrm{T}$ cell growth factor has also been suggested (40). The appearance of this membrane-anchored TNF molecule was an early phenomenon ( $1 \mathrm{~h}$ ) relative to more classical activation markers such as IL-2 R, which can be detected $6 \mathrm{~h}$ after anti-CD3 injection (4). Further support for this hypothesis comes from our results with an alternative approach to neutralizing TNF bioactivity, i.e., TBPI, the human recombinant soluble form of type I TNF receptor. TBPI pretreatment influenced neither anti-CD3-me- diated cytokine gene expression nor the production of the related proteins. We chose TBPI as an alternative TNF-neutralizing agent for its high protein sequence homology $(>65 \%)$ with its murine counterpart, its good reactivity with murine TNF (lack of species specificity), and its strong inhibition of the antiproliferative and anticytotoxic effects of TNF $(21,22,45-$ 47 ). The use of anti-TNF receptors antibodies was hampered by their suggested agonistic properties (45-47).

We thus speculate that cross-linking of membrane-anchored TNF via specific antibodies (or their $F\left(a b^{\prime}\right)_{2}$ bivalent fragments) or cell-surface TNF-receptors (but not their soluble forms), may account, in activated $\mathrm{T}$ cells, for the signal that modulates cytokine gene expression.

By extension, the described downregulation of IL-4 gene expression may involve a similar mechanism of signaling via membrane-associated TNF. Combined analysis of results from anti-TNF- and anti-IFN $\gamma$-pretreated mice reveals another regulatory pathway between IFN $\gamma$ on the one hand and IL-3 and IL- 6 on the other hand. Neutralization of anti-CD3-induced IFN $\gamma$ led to a significant increase in IL-3 and IL-6 mRNA levels, a mirror image of the effects of anti-TNF. There have been several reports of IFN $\gamma$-dependent negative modulation of IL-3. IFN $\gamma$ inhibits IL-3 production by cytotoxic $\mathrm{T}$ cell clones in vitro $(48,49)$. A similar effect occurs in aplastic anemia, in which high circulating levels of IFN $\gamma$ coexist with a characteristic deficiency in IL-3, GM-CSF, and erythropoietin (50). IFN $\gamma$ probably downregulates IL-3 gene expression by binding to specific receptors; the latter are usually expressed on activated $T$ cells, which, in our model, account for IL-3 production (51).

Although IFN $\gamma$ can potentiate TNF-induced IL-6 production indirectly (52), no direct IFN $\gamma$-IL-6 pathway has been described so far. Our results are compatible with IL-3 being the intermediate link between IFN $\gamma$ and IL-6. Furthermore, IL-6 is highly inducible by IL-3 in myelomonocytic progenitors and mature monocytes $(53,54)$.

Taken as a whole, these data have both clinical and fundamental relevance. Anticytokine $m A$ bs have been used for instance in the treatment of septic shock (anti-TNF) $(55,56)$, multiple myeloma (anti-IL-6) (57), experimental cerebral malaria (anti-TNF, anti-IFN $\gamma$, and anti-IL-3/GM-CSF) $(58,59)$, and murine leishmaniasis (anti-IL-4) (60). The main parameter used to investigate their mode of action is the blockade of the target cytokine's bioactivity, but it is essential to consider their effects on both cell-surface cytokines ( so far described for TNF, IL-1, IL-4, and IL-5) and their potential interference within cytokine networks $(40,61-63)$.

From a more fundamental point of view, cytokines may function as cell-surface-associated receptors with signal-transducing potential, although the precise mechanisms involved are unclear $(64,65)$. With regard to membrane-associated $\mathrm{TNF}$, it may conceivably play a role in $\mathrm{T}-\mathrm{T}$ cell cooperation by binding to TNF receptors, mainly of the type II p75kD form, which is highly expressed on activated T cells (66). A similar situation has been described for the TNF-related activation protein /CD40 couple (respectively expressed on activated $\mathrm{T}$ and $B$ cells) in modulating cytokine production and supporting T-B cooperation $(67,68)$. The functional relevance of this interaction is well illustrated by the hyper IgM syndrome associated with genetic gp 39 deficiency, which is an X-linked hereditary immunodeficiency $(69,70)$. 


\section{Acknowledgments}

The authors thank Dr. J. Bluestone for providing the anti-CD3 murine mAb, Dr. A. Ythier for providing TBPI, Drs. W. Paul, W. Roeder, and M. Dy for providing the murine cytokine probes. We are also indebted to Dr. M. C. Villa-Blasco for her help in membrane preparations, Western blotting, and constructive discussions; Ms. M. Calise for animal care, Ms. K. Steiner for skillful secretarial assistance, and Mr. D. Young for editing the English. We further acknowledge Dr. M. Dy for critical review of the manuscript.

\section{References}

1. Tracey, K. J., and A. Cerami. 1988. Cachectin/tumor necrosis factor and other cytokines in infectious diseases. Curr. Opin. Immunol. 1:454-461.

2. Kindler, V., A. P. Sappino, G. E. Grau, P. F. Piguet, and P. Vassali. 1989. The inducing role of tumor necrosis factor in the development of bactericidal granulomas during BCG infection. Cell. 56:731-740.

3. Bachwich, P. R., J. P. Lynch III, J. Larrick, M. Spengler, and S. L. Kunkel. 1986. Tumor necrosis factor production by human sarcoid alveolar macrophages. Am. J. Pathol. 125:421-425.

4. Hirsch, R., R. E. Gress, D. H. Pluznik, M. Eckhaus and J. A. Bluestone. 1989. Effects of in vivo administration of anti-CD3 monoclonal antibody on $T$ cell function in mice. II. In vivo activation of T cells. J. Immunol. 142:737-743.

5. Ferran, C., K. Sheehan, M. Dy, R. Schreiber, S. Merite, P. Landais, L. H. Noel, G. Grau, J. Bluestone, J. F. Bach, et al. 1990. Cytokine-related syndrome following injection of anti-CD3 monoclonal antibody: further evidence for transient in vivo T cell activation. Eur. J. Immunol. 20:509-515.

6. Ferran, C., M. Dy, K. Sheehan, S. Merite, R. Schreiber, P. Landais, G. Grau, J. Bluestone, J. F. Bach, and L. Chatenoud. 1991. Inter-mouse strain differences in the in vivo anti-CD3 induced cytokine release. Clin. Exp. Immunol. 86:537-543.

7. Alegre, M., P. Vandenabeele, V. Flamand, M. Moser, O. Leo, D. Abramowicz, J. Urbain, W. Fiers and M. Goldman. 1990. Hypothermia and hypoglycemia induced by anti-CD3 monoclonal antibody in mice; role of tumor necrosis factor. Eur. J. Immunol. 20:707-710.

8. Altman, A., K. M. Coggeshal and T. Mustelin. 1990. Molecular events mediating T cell activation. Adv. Immunol. 48:227-360.

9. Janeway C. A., Jr., and P. Golstein. 1991. Lymphocyte activation and effector functions. Curr. Opin. Immunol. 3:283-286.

10. Chatenoud, L., C. Legendre, C. Ferran, H. Kreis and J. F. Bach. 1991. Corticosteroid inhibition of the OKT3-induced cytokine-related syndrome-dosage and kinetics prerequisites. Transplantation (Baltimore). 51:334-338.

11. Ferran, C., M. Dy, K. Sheehan, R. Schreiber, G. Grau, J. Bluestone, J. F. Bach and $\mathrm{L}$. Chatenoud. 1991. Cascade modulation by anti-tumor necrosis factor monoclonal antibody of interferon- $\gamma$, interleukin 3 and interleukin 6 release after triggering of the CD3/T cell receptor activation pathway. Eur. J. Immunol. 21:2349-2353.

12. Charpentier, B., C. Hiesse, O. Lantz, C. Ferran, S. Stephens, D. O’Shaugnessy, M. Bodmer, D. Fries, J. F. Bach and L. Chatenoud. 1992. Anti-human tumor necrosis factor monoclonal antibody prevents OKT3-induced acute syndrome. Transplantation (Baltimore). 54:997-1002.

13. Darnell, J. E., Jr. 1982. Variety in the level of gene control in eukaryotic cells. Nature (Lond.). 297:365-371

14. Brorson, K. A., B. Beverly, S. M. Kang, M. Lenardo and R. H. Schwartz. 1991. Transcriptional regulation of cytokine genes in nontransformed T cells. $J$. Immunol. 147:3601-3609.

15. Swoboda, R., U. Bommhardt and A. Schimpl. 1991. Regulation of lymphokine expression in T cell activation. I. Rapid loss of interleukin-specific RNA after removal of the stimulating signal. Eur. J. Immunol. 21:1691-1695.

16. Lynn, D. A., L. M. Angerer, A. M. Bruskin, W. H. Klein and R. C. Angerer. 1983. Localization of a family of mRNAs in a single cell type and its precursors in sea urchin embryos. Proc. Natl. Acad. Sci. USA. 80:2656-2660.

17. Zinn, K., D. DiMaio and T. Maniatis. 1983. Identification of two distinct regulatory regions adjacent to the human $\beta$-interferon gene. Cell 34:865-879.

18. Leo, O., M. Foo, D. H. Sachs, L. E. Samelson and J. A. Bluestone. 1987. Identification of a monoclonal antibody specific for a murine T3 polypeptide. Proc. Natl. Acad. Sci. USA. 84:1374-1378.

19. Sheehan, K. C. F., N. H. Ruddle and R. D. Schreiber. 1989. Generation and characterization of hamster monoclonal antibodies that neutralize murine tumor necrosis factors. J. Immunol. 142:3884-3893.

20. Schreiber, R. D., L. J. Hicks, A. Celada, N. A. Buchmeier and P. W. Gray. 1985. Monoclonal antibodies to murine $\gamma$-interferon which differentially modulate macrophage activation and antiviral activity. J. Immunol. 134:1985-1989.

21. Lewis, M., L. A. Tartaglia, A. Lee, G. L. Benett, G. C. Rice, G. H. W. Wong, E. Y. Chen and D. V. Goeddel. 1991. Cloning and expression of cDNAs for two distinct murine tumor necrosis factor receptors demonstrate one receptor is species specific. Proc. Natl. Acad. Sci. USA. 88:2830-2834.

22. Higushi, M., and B. B. Aggarwal. 1992. Inhibition of ligand binding and antiproliferative effects of tumor necrosis factor and lymphotoxin soluble forms of recombinant $\mathrm{P} 60$ and $\mathrm{P} 80$ receptors. Biochem. Biophys. Res. Commun. 182:638-643.

23. Chomczynski, P., and N. Sacchi. 1987. Single-step method of RNA isolation by acid guanidinium thiocyanate-phenol-chloroform extraction. Anal. Biochem. 162:156-159.

24. Melton, D. A., P. A. Krieg, M. R. Rebagliati, T. Maniatis, K. Zinn and M. R. Green. 1984. Efficient in vitro synthesis of biologically active RNA and RNA hybridization probes from plasmids containing a bacteriophage SP6 promoter. Nucleic Acids Res. 12:703.

25. Fransen, L., R. Müller, A. Marmenout, J. Tavernier, J. Van der Heyden, E. Kawashima A. Chollet, R. Tizard, H. Van Heuverswyn, A. Van Vliet, et al. 1985. Molecular cloning of mouse tumour necrosis factor cDNA and its eukaryotic expression. Nucleic Acids Res. 13:4417-4429.

26. Dunn, D. E., K. C. Herold, G. R. Otten, D. W. Lancki, T. Gajewski, S. N. Vogel and F. W. Fitch. 1987. Interleukin 2 and concanavalin a stimulate interferon- $\gamma$ production in a murine cytolytic $T$ cell clone by different pathways. $J$. Immunol. 139:3942-3948.

27. Miyatake, S., T. Yokato, F. Lee and K. Arai. 1985. Structure analysis of the chromosomal gene for murine interleukin 3. Proc. Natl. Acad. Sci. USA. 82:316-318.

28. Ohara, J. and W. E. Paul. 1985. Production of a monoclonal antibody to and molecular characterization of B-cell stimulatory factor-1. Nature (Lond.). 315:333-336.

29. Van Snick, J., S. Cayphas, J. P. Szikora, J. C. Renauld, E. Van Roost, E. T. Boon, and R. J. Simpson. 1988. cDNA cloning of murine interleukin-HP1: homology with human interleukin 6. Eur. J. Immunol. 18:193-197.

30. Laemmli, K. 1970. Cleavage of structural proteins during the assembly of the head of bacteriophage T4. Nature (Lond.). 227:680-685.

31. Burnette, W. N. 1981. Western blotting electrophoretic transfer of proteins from sodium sodecyl sulfate polyacrylamide gels to unmodified nitrocellulose and radiographic detection with antibody and radioiodinated protein $\mathrm{A}$. Anal. Biochem. 112:195-203.

32. Ozato, K., N. M. Mayer and D. H. Sachs. 1982. Monoclonal antibodies to mouse major histocompatibility complex antigens. IV. A series of hybridoma clones producing anti-H- $2^{d}$ antibodies and an examination of expression of $\mathrm{H}-2^{\mathrm{d}}$ antigens on the surface of these cells. Transplantation (Baltimore). 34:113-120.

33. Kriegler, M., C. Perez, K. DeFay, I. Albert and S. Lu. 1988. A novel form of TNF/cachectin is a cell surface cytotoxic transmembrane protein: ramifications for the complex physiology of TNF. Cell. 53:45-53.

34. Chensue, S. W., D. G. Remick, C. Shmyr-Forsch, T. F. Beals and S. L. Kunkel. 1988. Immunohistochemical demonstration of cytoplasmic and membrane-associated tumor necrosis factor in murine macrophages. Am. J. Pathol. 133:564-572.

35. Kinkhabwala, M., P. Shejpal, E. Skolnik, D. Smith, V. Sharma, H. Vlassara, A. Cerami and M. Suthanthiran. 1990. A novel addition to the T repertory. Cell surface expression of tumor necrosis factor/cachectin by activated normal human T cells. J. Exp. Med. 171:941-946.

36. Scott, D. E., W. C. Gause, F. D. Finkelman and A. D. Steinberg. 1990. Anti-CD3 antibody induces rapid expression of cytokine genes in vivo. $\mathrm{J}$. Immunol. 145:2183-2188.

37. Kindler, V., A. Sappino, G. Grau, P. Piguet and P. Vassalli. 1989. The inducing role of tumor necrosis factor in the development of bactericidal granulomas during BCG infection. Cell. 56:731-740.

38. Cuturi, M. C., M. Murphy, M. P. Costa-Giomi, R. Weinmann, B. Perussia and G. Trinchieri. 1987. Independant regulation of tumor necrosis factor and lymphotoxin production by human peripheral blood lymphocytes. J. Exp. Med. 165:1581-1584.

39. Sung, S. S. J., J. M. Bjorndahl, C. Y. Wang, H. T. Kao and S. M. Fu. 1988. Production of tumor necrosis factor/cachectin by human $\mathrm{T}$ cell lines and peripheral blood $\mathrm{T}$ lymphocytes stimulated by phorbol myristate acetate and anti-CD3 antibody. J. Exp. Med. 167:937-953.

40. Vassali, P. 1992. The pathophysiology of tumor necrosis factor. Annu. Rev. Immunol. 10:411-452.

41. Hirsch, R., J. A. Bluestone, L. De Nenno and R. E. Gress. 1990. Anti-CD3 $F\left(a b^{\prime}\right) 2$ fragments are immunosuppressive in vivo without evoking either the strong humoral response or morbidity associated with whole mAb. Transplantation (Baltimore). 49:1117-1123.

42. Lindsten, T., C. H. June, J. A. Ledbetter, G. Stella and C. B. Thompson. 1989. Regulation of lymphokine messenger RNA stability by a surface-mediated T cell activation pathway. Science (Wash. DC). 244:339-343.

43. Luettig, B., T. Decker and M. L. Lohmann-Matthes. 1989. Evidence for the existence of two forms of membrane tumor necrosis factor: an integral protein and a molecule attached to its receptor. J. Immunol. 143:4034-4038.

44. Smith, R. A. and C. Baglioni. 1987. The active form of tumor necrosis factor is a trimer. J. Biol. Chem. 262:6951-6954. 
45. Van Zee, K. J., T. Kohno, E. Fischer, C. S. Rock, L.L. Moldawer and S. F. Lowry. 1992. Tumor necrosis factor soluble receptors circulate during experimental and clinical inflammation and can protect against excessive tumor necrosis factor $\alpha$ in vitro and in vivo. Proc. Natl. Acad. Sci. USA. 89:4845-4849.

46. Aderka, D., H. Engelmann, Y. Maor, C. Brakebusch and D. Wallach. 1992. Stabilization of the bioactivity of tumor necrosis factor by its soluble receptors. J. Exp. Med. 175:323-329.

47. Nophar, Y., O. Kemper, C. Barkebush, H. Engleman, R. Zwang, D. Aderka, H. Holtmann, and D. Wallach. 1990. Soluble forms of tumor necrosis factor receptors (TNF-Rs). The cDNA for the type 1 TNF-R, cloned using amino acid sequence data of its soluble form, encodes both the cell surface and a soluble form of the receptor. EMBO (Eur. Mol. Biol. Organ.) J. 9:3269-3278.

48. Gajewski, T., and F. W. Fitch. 1990. Anti-proliferative effect of IFN- $\gamma$ in immune regulation. IV. Murine CTL clones produce IL-3 and GM-CSF, the activity of which is masked by the inhibitory action of secreted IFN- $\gamma . J . I m$ munol. 144:548-556.

49. Gajewski, T. F., and F. W. Fitch. 1988. Anti-proliferative effect of IFN- $\gamma$ in immune regulation. I. IFN- $\gamma$ inhibits the proliferation of Th2 but not Th1 murine helper T lymphocyte clones. J. Immunol. 140:4245-4252.

50. Zoumbos, N. C., P. Gascon, J. Y. Djeu and N. S. Young. 1985. Interferon is a mediator of hematopoietic suppression in aplastic anemia in vitro and possibly in vivo. Proc. Natl. Acad. Sci. USA. 82:188-192.

51. Valente, G., L. Ozmen, F. Novelli, M. Geuna, G. Palestro, G. Forni and G. Garotta. 1992. Distribution of interferon- $\gamma$ receptor in human tissue. Eur. J. Immunol. 22:2403-2412.

52. Brouckaert, P., D. R. Spriggs, G. Demetri, D. W. Kufe and W. Fiers. 1989. Circulating interleukin 6 during a continuous infusion of tumor necrosis factor and interferon $\gamma$. J. Exp. Med. 169:2257-2262.

53. Schneider, E., R. E. Ploemacher, S. Navarro, C. Van Beurden and M. Dy. 1991. Characterization of murine hematopoietic progenitor subsets involved in interleukin-3-induced interleukin-6 production. Blood. 78:329-338.

54. Frendl, G., M. J. Fenton and D. I. Beller. 1990. IL-3 regulates TNF $\alpha$, IL-1 and IL-6 expression in monocytes. Lymphokine Res. 9:616.

55. Tracey, K. J., Y. Fong, D. G. Hesse, K. R. Manogue, A. T. Lee, G. C. Kuo, S. F. Lowry and A. Cerami. 1987. Anti-cachectin/TNF monoclonal antibodies prevent septic shock during lethal bacteraemia. Nature (Lond.). 330:662-664.

56. Exley, A. R., J. Cohen, W. Buurman, R. Owen, G. Hanson, J. Lumley, J. M. Aulakh, M. Bodmer, A. Riddel, S. Stephens, et al. 1990. Monoclonal antibody to TNF in severe septic shock. Lancet. 1:1275-1278.

57. Klein, B., J. Wijdeness, X. G. Zang, M. Jourdan, J. M. Boiron, J. Brochier, J. Liautard, M. Merlin, C. Clement, B. Morel-Fournier, et al. 1991. Murine anti-interleukin 6 monoclonal antibody therapy for a patient with plasma cell leukemia. Blood. 78:1198-1204.
58. Grau, G. E., V. Kindler, P. F. Piguet, P. H. Lambert and P. Vassalli. 1988. Prevention of experimental cerebral malaria by anticytokine antibodies. Interleukin 3 and granulocyte macrophage colony-stimulating factor are intermediates in increased tumor necrosis factor production and macrophage accumulation. $J$. Exp. Med. 168:1499-1504.

59. Grau, G. E., H. Heremans, P. F. Piguet, P. Pointaire, P. H. Lambert, A. Billiau and P. Vassalli. 1989. Monoclonal antibody against interferon $\gamma$ can prevent against experimental cerebral malaria and its associated overproduction of tumor necrosis factor. Proc. Natl. Acad. Sci. USA. 86:5572-5574.

60. Sadick, M. D., F. P. Heinzel, B. J. Holaday, R. T. Pu, R. S. Dawkins and R. M. Locksley. 1990. Cure of murine leishmaniasis with anti-interleukin 4 monoclonal antibody. Evidence for a T cell-dependent, interferon $\boldsymbol{\gamma}$-independent mechanism. J. Exp. Med. 171:115-127.

61. Dinarello, C. 1988. The biology of interleukin 1. FASEB (Fed. Am. Soc. Exp. Biol.) J. 50:108-115.

62. Brian, A. A. 1988. Stimulation of B-cell proliferation by membrane-associated molecules from activated T cells. Proc. Natl. Acad. Sci. USA. 86:42354239 .

63. Fernandez-Botran, R., J. W. Uhr and E. S. Vitetta. 1989. Cross-linking of interleukin 4 to surface molecules on murine T and B lymphocytes. Proc. Natl. Acad. Sci. USA. 86:4235-4239.

64. Birnbaumer, L. 1992. Receptor-to-effector signaling through $\mathbf{G}$ proteins: roles for $\beta \gamma$ dimers as well as $\alpha$ subunits. Cell. 71:1069-1072.

65. Blackshear, P. J., A. C. Nairn and J. F. Kuo. 1988. Protein kinases 1988: a current perspective. FASEB (Fed. Am. Soc. Exp. Biol.) J. 2:2957-2969.

66. Vandenabeele, P., W. Declercq, D. Vercammen, M. Van de Graen, J. Grooten, H. Loetscher, M. Brockhaus, W. Lesslauer and W. Fiers. 1992. Functional characterization of the human tumor necrosis factor receptor p75 in a transfected Rat/Mouse T cell hybridoma. J. Exp. Med. 176:1015-1024.

67. Hollenbaugh, D., L. S. Grosmaire, C. D. Kullas, N. J. Chalupny, S. Braesch-Andersen, R. J. Noelle, I. Stamenkovic, J. A. Ledbetter and A. Aruffo. 1992. The human T cell antigen gp39, a member of the TNF gene family, is a ligand for the CD40 receptor: expression of a soluble form of $\mathrm{gp} 39$ with B cel co-stimulatory activity. EMBO (Eur. Mol. Biol. Organ.) J. 11:4313-4321.

68. Graf, D., U. Korthäuer, H. W. Mages, G. Senger, R. A. Kroczek. 1992. Cloning of TRAP, a ligand for CD40 on human T cells. Eur. J. Immunol. 22:3191-3194.

69. Aruffo, A., M. Farrington, D. Hollenbaugh, X. Li, A. Milatovitch, S. Nonoyama, J. Bajorath, L. S. Grosmaire, R. Stenkamp, M. Neubauer, et al. 1993. The CD40 ligand, gp 39 is defective in activated T cells from patients with Xlinked hyper IgM syndrome. Cell. 72:291-300.

70. Disanto, J. P., J. Y. Bonnefoy, J. F. Gauchat, A. Fischer, and G. de Sain basile. 1993. CD40 ligand mutations in X-linked immunodeficiency with hyperIgM. Nature (Lond.). 361:541-543. 